\title{
Contribution of epilithic diatoms to benthic-pelagic coupling in a temperate river
}

\author{
N. Tekwani ${ }^{1,2}$, N. Majdi ${ }^{1,2}$, B. Mialet ${ }^{3}$, E. Tornés ${ }^{4,5}$, G. Urrea-Clos ${ }^{4}$, \\ E. Buffan-Dubau ${ }^{1,2}$, S. Sabater ${ }^{4,5}$, M. Tackx ${ }^{1,2, *}$ \\ ${ }^{1}$ Université de Toulouse, INP, UPS, UMR 5245 Ecologie fonctionnelle et environnement (EcoLab), 31062 Toulouse, France \\ ${ }^{2}$ CNRS, EcoLab, 31062 Toulouse, France \\ ${ }^{3}$ Université de La Rochelle-CNRS, UMR 7266 Littoral environnement et sociétés (LIENSs), 17000 La Rochelle, France \\ ${ }^{4}$ Universitat de Girona, Institute of Aquatic Ecology, 17071 Girona, Spain \\ ${ }^{5}$ Catalan Institute for Water Research (ICRA), 17003 Girona, Spain
}

\begin{abstract}
Water residence time in the middle course of rivers is often too short to allow substantial phytoplankton development, and primary production is essentially provided by benthic phototrophic biofilms. However, cells occurring in the water column might derive from biofilm microalgae, and, reciprocally, sedimenting microalgae could represent a continuous source of colonizers for benthic biofilms. A comparative study of biofilm and pelagic microphytic communities (with special focus on diatoms) was carried out over 15 mo in the Garonne River, France. Diatoms dominated both biofilm and pelagic microphytic communities. Typically benthic diatoms were found in high abundance in the water column, and their biomass in the water was correlated with their biomass in the biofilm, indicating the benthic origin of these cells. Variations in river discharge and temperature drove the temporal distribution of benthic and pelagic communities: under high flow mixing (winter) communities showed the greatest similarity, and during low flow (summer) they differed the most. Even during low flow, typical benthic species were observed in the water column, indicating that benthic-pelagic exchanges were not exclusively due to high water flow. Moreover, during low flow periods, planktonic diatoms typically settled within biofilms, presumably because of higher water residence times, and/or upstream reservoir flushing.
\end{abstract}

KEY WORDS: Periphyton · Distribution · Biofilm · Microphytobenthos $\cdot$ Phytoplankton · Algal ecology $\cdot$ Community structure $\cdot$ HPLC

\section{INTRODUCTION}

Rivers carry drifting and in situ-produced organic matter and organisms as a result of physical-chemical conditions and their corresponding biological responses. Planktonic organisms are produced in situ, but their occurrence is mostly restricted to large rivers or sheltered areas (Vannote et al. 1980, Basu \& Pick 1996). In headwaters, heavy canopy cover and high water velocity are incompatible with substantial phytoplankton development (e.g. Reynolds et al. 1994). In estuarine reaches the water residence time is higher and can favour suspended primary producers, though surface turbidity can still limit phyto- plankton production (Phlips et al. 2000) and constrain phytobenthos to a limited area (e.g. Soetaert \& Herman 1995). In the middle course of large rivers, the water residence time is critical to allow substantial phytoplankton development. Phytoplankton develops mostly in slowly moving waters (Sabater et al. 2008), but when the channel is shallow and waters are moving fast, light penetration favours the development of phytobenthic organisms. Hence, in these stretches, phytobenthic production is essential for sustaining the riverine food web (Lawrence et al. 2002, Liess \& Hillebrand 2004, Dodds 2006), as well as the key biogeochemical processes occurring in the river (Battin et al. 2003, Teissier et al. 2007). 
Benthic algae on the river bed are generally associated with heterotrophic microorganisms (bacteria, flagellates and ciliates) embedded in a mucous matrix composed of exopolymeric exudates (EPS) and trapped detritic and mineral particles, to form biofilms (Lock et al. 1984, Romaní et al. 2004). These biofilms are shaped by abiotic and biotic influences (e.g. light, flow, nutrients, grazing, allelopathy) that affect their structure and functions (e.g. Hillebrand 2002, Sabater et al. 2002, Lyautey et al. 2005a, Boulêtreau et al. 2006, Leflaive \& Ten-Hage 2007, Mathieu et al. 2007). The dynamics of epilithic biofilms include a growth phase, corresponding to an ecological succession of microbial colonizers onto the substratum (e.g. Korte \& Blinn 1983, Lyautey et al. 2005a), and a detachment phase. Detachment of components of the biofilm can occur either through flow abrasion and/or through self-detachment processes (Biggs \& Close 1989, Boulêtreau et al. 2006). Also meio- and macrofauna drilling and grazing the biofilm influence its architecture and growth dynamics (Lawrence et al. 2002, Gaudes et al. 2006, Kathol et al. 2011). In the middle course of fast-moving rivers, cells occurring in the water column are derived essentially from the detachment of phototrophic biofilms (Roeder 1977, Ameziane et al. 2003). Conversely, drifting microalgae could represent a continuous source of colonizers for benthic biofilms, implying a certain upstream-downstream connectivity of microphytobenthic communities (Pusch et al. 1998).

The potential couplings between biofilm and pelagic microalgae in the middle course of the Garonne River (France) were analysed according to their respective community structure. Emphasis was placed on diatoms since they dominate the biofilm microphytobenthic community in the middle course of the Garonne River (Leflaive et al. 2008, Majdi et al. 2011). We specifically aimed to (1) determine whether biofilm export to the water column was continuous or whether it mainly occurred after floods and (2) determine the key environmental factors influencing benthic-pelagic coupling and diatom community structure and similarity between benthic and pelagic communities.

\section{MATERIALS AND METHODS}

\section{Study site}

The Garonne River is the largest river of southwestern France $\left(647 \mathrm{~km}\right.$ length, $57000 \mathrm{~km}^{2}$ catchment area). It rises in the Pyrenees Mountains, and displays a flow regime characterized by an intense spring-flood period after snowmelt, followed by a long low flow water period for the rest of the year. This low flow period is interrupted only by flash floods caused by heavy rainfall. The Garonne's river bed consists mainly of shallow alternating cobble bars. A thick diatom-dominated biofilm colonizes the upper surface of cobbles, especially during low flow periods (Majdi et al. 2012a). Sampling was conducted at a cobble bar in a sixth-order stretch of the Garonne River, $36 \mathrm{~km}$ upstream of the city of Toulouse (Fig. 1; longitude: 432 $23^{\prime} 45^{\prime \prime} \mathrm{N}$; latitude: 01 17' 53" E; elevation: $175 \mathrm{~m}$ above sea level [a.s.1.]). The epilithic microbial and invertebrate communities at this site are described elsewhere (Lyautey et al. 2005b, Leflaive et al. 2008, Majdi et al. 2011, 2012a). The canopy is open, but the residence time is too short for substantial phytoplankton development, and benthic biofilms provide most of the primary production (Ameziane et al. 2002, 2003).

\section{Sample collection}

Epilithic biofilms were sampled weekly from December 2008 to March 2010 ( $\mathrm{n}=48$ ), when the river remained wadeable (discharge $<175 \mathrm{~m}^{3} \mathrm{~s}^{-1}$ ). On each sampling occasion, we randomly collected 12 cobbles (mean diameter $=10 \mathrm{~cm}$ ) by sliding them into a plastic bag underwater $($ depth $=30$ to $50 \mathrm{~cm}$ ). The biofilm

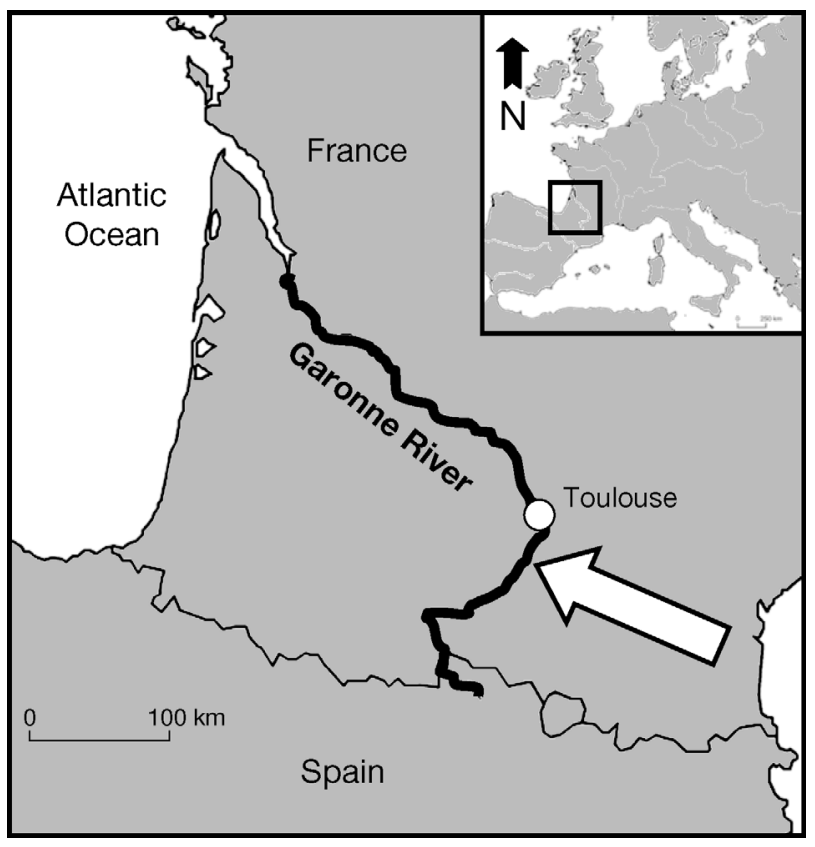

Fig. 1. Location of the study site at the Garonne River, France 
was gathered by scraping the total upper surface of each cobble with a scalpel and toothbrush. Then biofilm samples were suspended in ultrapure water (Milli-Q filtration; Millipore) to obtain the respective biofilm suspensions ( $25 \mathrm{ml}$ each). These suspensions were divided into 3 groups of 4 replicates to be used for meiofaunal counts, algal pigment analyses and estimation of epilithic ash-free dry mass (AFDM). The procedures are detailed in Majdi et al. $(2011,2012 a)$.

One large cobble (mean diameter $=30 \mathrm{~cm}$ ) was additionally collected from October 2008 to March $2010(n=19)$, and the biofilm was scraped off from its entire upper surface with a scalpel and toothbrush. This biofilm sample was preserved with formaldehyde (final concentration $=4 \%$ ) for the identification of benthic (biofilm) diatoms.

Simultaneously, river water in the upper $10 \mathrm{~cm}$ of the water column was collected for (1) pelagic diatom identification (4 replicate $125 \mathrm{ml}$ water samples preserved with Lugol's solution, Sigma-Aldrich) and (2) pelagic phytopigment measurement. For the latter, 3 replicate $500 \mathrm{ml}$ water samples were filtered onto 1.2 $\mu \mathrm{m}$ glass fibre filters (GF/C, Whatman), which were immediately folded in aluminium and then preserved in liquid $\mathrm{N}_{2}$, and stored in the laboratory at $-80^{\circ} \mathrm{C}$ until analysed.

\section{Physical and chemical characteristics}

The mean daily discharge (MDD) was supplied by a gauging station of the French water management authority (DIREN Midi-Pyrénées, Marquefave station) located $10 \mathrm{~km}$ upstream of the study site. No tributaries or dams occur between the gauging station and the study site. Water height and streambed flow velocity were measured (mean of 3 measurements flanking the sampling area) on each sampling occasion with a flowmeter (Flo-Mate 2000, FlowTronic). Days after flood were estimated as the number of days between a given sampling occasion and the last critical flood (MDD $>300 \mathrm{~m}^{3} \mathrm{~s}^{-1}$; Majdi et al. 2012a). Water temperature, conductivity, $\mathrm{pH}$ and dissolved $\mathrm{O}_{2}$ were measured with an automated multiparameter probe (YSI 6000, Yellow Springs Instruments), which was permanently set $5 \mathrm{~cm}$ above the streambed.

\section{Phytopigment analysis}

Four biofilm suspensions were centrifuged (3220 $\times g, 20 \mathrm{~min}$ ), and the obtained pellets were freeze- dried. We removed $250 \mathrm{mg}$ subsamples from each pellet and extracted biofilm algal pigments in 3 steps. A total of $25 \mathrm{ml}(10,10$ and $5 \mathrm{ml})$ mixture of $98 \%$ cold-buffered methanol and $2 \%$ of $1 \mathrm{M}$ ammonium acetate was used for the extraction. Each subsequent step consisted of $15 \mathrm{~min}$ extraction at $-20^{\circ} \mathrm{C}$. For pelagic phytopigment extraction, frozen GF/C filters were cut into small pieces in centrifuge tubes containing $5 \mathrm{ml}$ of $98 \%$ cold-buffered methanol (with $2 \%$ of $1 \mathrm{M}$ ammonium acetate). Pigment extraction was promoted by $250 \mathrm{~W}$ ultrasonication for $30 \mathrm{~s}$ (Sonifier 250A, Branson Ultrasonics). Then, pigment extracts were incubated for $15 \mathrm{~min}$ at $-20^{\circ} \mathrm{C}$ before centrifugation. The extracts were finally centrifuged $(3220 \times g$, $3 \mathrm{~min})$ to settle filter pieces.

For both biofilm and pelagic phytopigment analyses, $1 \mathrm{ml}$ of the pigment extract was filtered through a $0.2 \mu \mathrm{m}$ polytetrafluoroethylene syringe filter, and the filtrate was analysed with a high-performance liquid chromatograph consisting of a $100 \mu \mathrm{l}$ loop autosampler and a quaternary solvent delivery system coupled to a diode array spectrophotometer (LC1200 series, Agilent Technologies) through a C8 column $(4.6 \times 100 \mathrm{~mm}, 3 \mu \mathrm{m}$, Thermo $)$. The mobile phase was set after Barlow et al. (1997). Microphytic pigments were determined and quantified by comparing their retention time and absorption spectra with those of reference pure standards (DHI LAB products; see Majdi et al. 2011 for further details). Biofilm and pelagic phytopigment concentrations were both expressed per surface units (e.g. $\mathrm{mg} \mathrm{m}^{-2}$ ), by considering the sampled surface for the biofilm, or by considering the water height for the water column.

We performed chemotaxonomic analysis with the CHEMTAX software (Version 1.95; Mackey et al. 1996) to derive the biomass of biofilm and pelagic microphythic groups from their contribution to total chlorophyll a (chl a). Biomarker pigment ratios were used from Majdi et al. (2011) to supply the initial matrix required to run the chemotaxonomic analysis.

\section{Diatom identification}

The 4 water sample replicates were pooled and thoroughly homogenized before a 20 to $50 \mathrm{ml}$ (depending on diatom concentration) subsample was placed in a settling chamber. Diatoms were allowed to settle for 20 to $50 \mathrm{~h}$ depending on subsample volume. Diatom cell contents were digested with $\mathrm{HCl}$ $(37 \%)$ and subsequently heated at $100^{\circ} \mathrm{C}$ for $2 \mathrm{~h}$ with $\mathrm{H}_{2} \mathrm{O}_{2}$ (Biggs \& Kilroy 2000). The heating step was repeated twice. Resulting cleaned frustules were 
rinsed with ultrapure water on a $0.2 \mu \mathrm{m}$ pore filter and finally suspended in 1 to $3 \mathrm{ml}$ ultrapure water. A subsample of $200 \mu \mathrm{l}$ was pipetted onto a coverslip and permanently preserved in Naphrax ${ }^{\circledR}$ mounting medium (Northern Biological Supplies). The same procedures were applied to biofilm samples, except for the settlement step. At least 400 diatoms were counted under a light microscope at 1000× magnification, identified to species level and attributed to benthic or pelagic habitats, according to their distribution in inland waters after Krammer \& LangeBertalot (1991). Pennate diatoms were mostly classified as benthic, whereas centric diatoms were mostly classified as planktonic.

Diatoms were also categorized by their morphology and growth-form (solitary, prostrated, erected, or chained) and mobility (mobile or immobile), based on Hudon \& Legendre (1987), DeNicola et al. (2006) and Passy (2007). Data were expressed as the relative contributions of every taxon to total diatom abundance.

\section{Data analysis}

Spearman rank correlation analyses were used to explore the couplings between biofilm and pelagic phytopigments, using STATISTICA software (Version 8.0, Statsoft). The influence of biotic and abiotic factors on diatom species distribution in the biofilm and in the water column was examined by means of multivariate analysis, using CANOCO software (Version 4.5, Biometris). Rare species (contribution $<1 \%$ ) were not considered. The relative species abundances were square-root transformed prior to the analysis. Diatom species distribution was first analysed by a detrended correspondence analysis. As the total inertia observed was $<2.6$, a predominance of linear species response was expected (Ter Braak 1987, 1994). Hence, a redundancy analysis (RDA) was applied, in which the ordination axes were constrained to be linear combinations of provided environmental factors. Factors were listed according to the variance (eigenvalues: $\lambda$ ) explained by each factor when added to the model, discarding possi- ble co-variability with other factors (conditional effects; Ter Braak \& Smilauer 2002). More specific details about this method are given by Borcard et al. (1992). The statistical significance was checked using a Monte Carlo permutation test (499 unrestricted permutations, $\alpha=0.05$ ).

An analysis of similarity (ANOSIM) using non-metric multidimensional scaling (nMDS) was performed to explore the similarity between biofilm and pelagic diatom communities regarding discharge and temperature constraints, with the PRIMER software (Version 5, PRIMER-E). The ANOSIM was based on BrayCurtis similarity calculated from non-transformed species relative abundances. $\mathrm{R}$ has an absolute interpretation of its value that is potentially more meaningful than its statistical significance: large R-values, close to 1 , indicate a clear separation of the communities, whereas small values, close to 0 , imply little or no separation (Clarke \& Warwick 2001). Samples were then presented on a nMDS biplot according to their diatom community similarities with other sam-

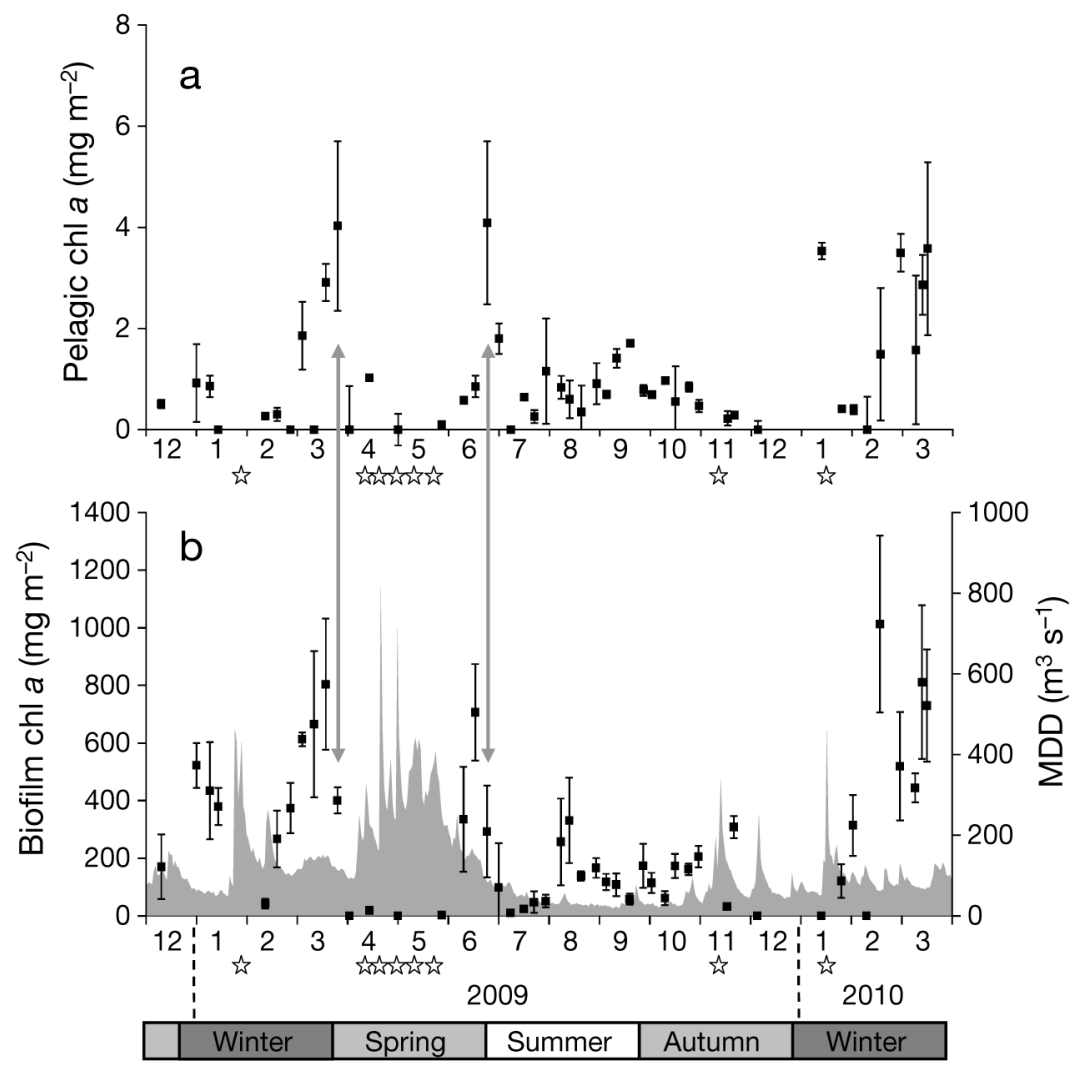

Fig. 2. Temporal dynamics of (a) chlorophyll a ( $\mathrm{chl} \mathrm{a}$ ) in the water column (mean $\pm \mathrm{SE}, \mathrm{n}=3$ ) and (b) mean daily discharge (MDD) and chl $a$ in the epilithic biofilm (mean $\pm \mathrm{SE}, \mathrm{n}=4$ ). Black squares: chl $a_{\text {; }}$ shaded area: MDD. Months (where 1: January, 2: February, etc.), years, seasons and critical floods during which MDD $>300 \mathrm{~m}^{3} \mathrm{~s}^{-1}$ (represented by stars) are indicated on the $x$-axis. Grey arrows represent the $1 \mathrm{wk}$ lag observed between biofilm and pelagic chl a maxima 


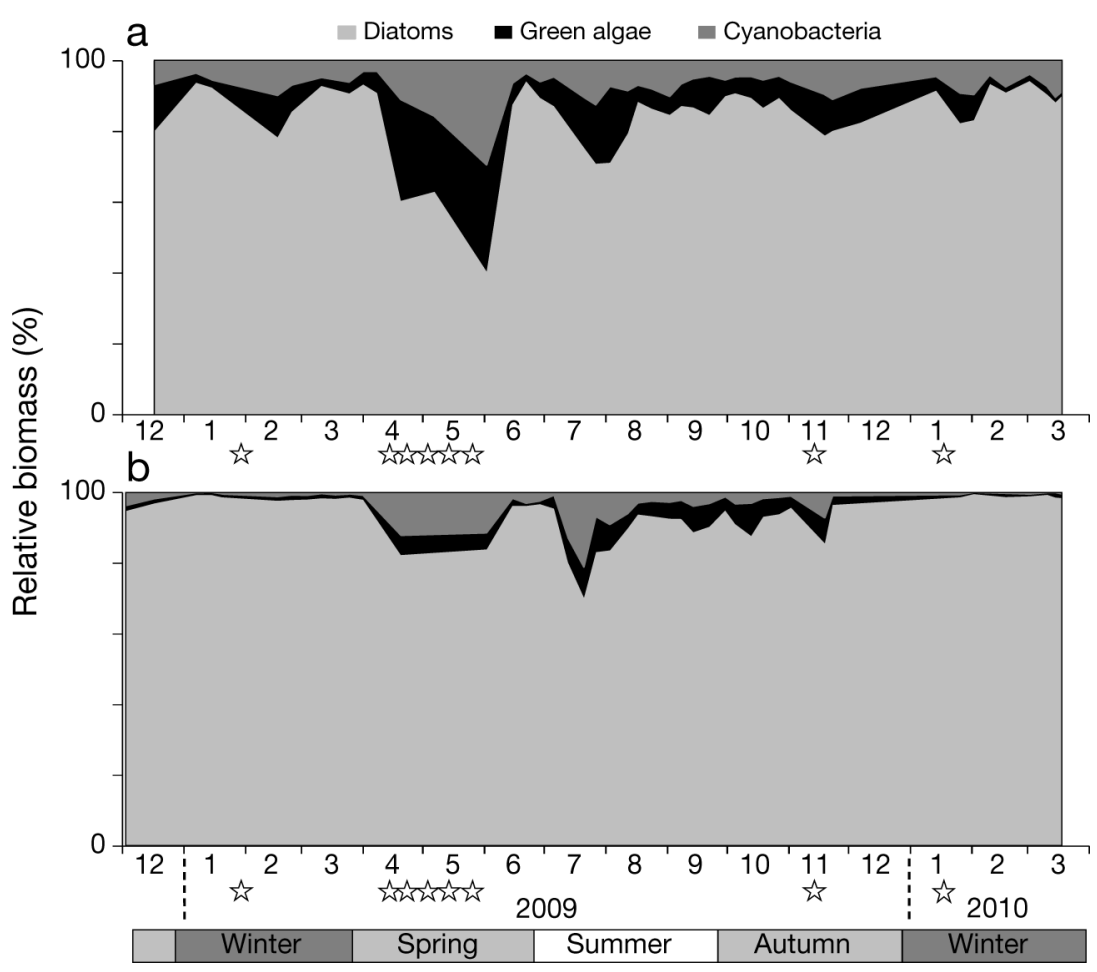

Fig. 3. Relative biomass of microphytic groups (a) in the water column and (b) in the epilithic biofilm. Months, years, seasons and critical floods during which MDD $>300 \mathrm{~m}^{3} \mathrm{~s}^{-1}$ (represented by stars) are indicated on the $x$-axis

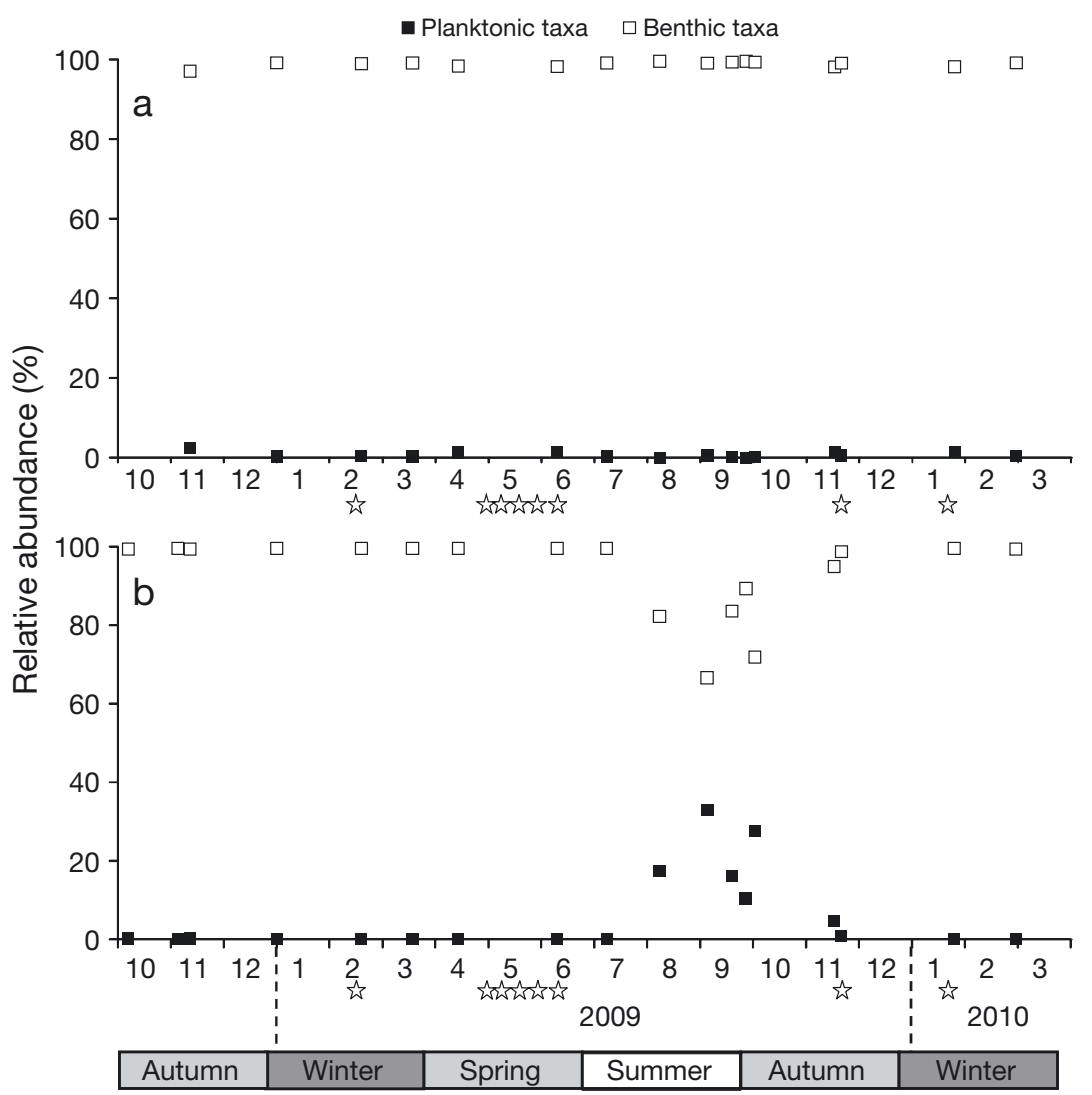

ples. On the same plot, samples were sorted into groups according to discharge constraints (low: 0 to 50, medium: 51 to 100 , and high: $>100 \mathrm{~m}^{3}$ $\mathrm{s}^{-1}$ ) and according to temperature constraints (low: 0 to 9, medium: 9 to 17 , and high: $>17^{\circ} \mathrm{C}$ ).

\section{RESULTS}

\section{Microalgal dynamics and benthic-pelagic couplings}

Chl a averaged $287 \mathrm{mg} \mathrm{m}^{-2}$ (ranging from 3 to $1012 \mathrm{mg} \mathrm{m}^{-2}$ ) in the biofilm and $0.8 \mathrm{mg} \mathrm{m}^{-2}$ (0.1 to $4.1 \mathrm{mg} \mathrm{m}^{-2}$ ) in the water column (Fig. 2). Hence, the algal biomass in the water was negligible compared to that in the biofilm.

Biofilm and pelagic chl a showed considerable variations throughout the study period: they both tended to increase during periods of low flow, whereas they sharply decreased after floods (Fig. 2). The biofilm and pelagic chl a dynamics were correlated (Spearman rank correlation, $\mathrm{n}=38, \mathrm{r}=0.53$, $p<0.001$ ). Some of the declines in chl $a$ in the biofilm (e.g. late March and June 2009) corresponded to a lagged pelagic chl a decline (Fig. 2). From August to October 2009, biofilm and pelagic chl a dynamics followed opposite patterns.

The CHEMTAX analysis showed that diatoms dominated the microphytic biomass both in the biofilm and in the water column (Fig. 3). Biofilm and pelagic fucoxanthin (i.e. diatom biomarker pigment) were strongly correlated (Spearman, $\mathrm{n}=$ $38, r=0.61, p<0.001$ ). Cyanobacteria and green algae contributed to the

Fig. 4. Relative abundance of typically planktonic and typically benthic diatom species after Krammer \& Lange-Bertalot (1991) found (a) in the water column and (b) in the epilithic biofilm. Months, years, seasons and critical floods during which MDD $>300 \mathrm{~m}^{3} \mathrm{~s}^{-1}$ (represented by stars) are indicated on the $\mathrm{X}$-axis 
Table 1. Code, occurrence in the present study, type after Krammer \& Lange-Bertalot (1991), mobility and growth form after Hudon \& Legendre (1987), DeNicola et al. (2006) and Passy (2007), and mean contribution of the most common diatoms that were considered in the redundancy analysis (i.e. with a community contribution $>1 \%$ in at least 1 sample). Species affinities $(+,-)$ with discharge conditions were computed from the redundancy analysis. B: biofilm; P: pelagos; i: immobile; m: mobile; p: prostrated; e: erected; s: solitary centric; c: chained

\begin{tabular}{|c|c|c|c|c|c|c|c|c|}
\hline \multirow[t]{2}{*}{ Code } & \multirow[t]{2}{*}{ Species and authority } & \multirow[t]{2}{*}{ Occurrence } & \multirow[t]{2}{*}{ Type } & \multirow[t]{2}{*}{ Mobility } & \multirow{2}{*}{$\begin{array}{l}\text { Growth } \\
\text { form }\end{array}$} & \multicolumn{3}{|c|}{ Contribution (\%) } \\
\hline & & & & & & Biofilm & Pelagos & \\
\hline abia & Achnanthidium biasolettianum (Grun.) Round \& Bukhtiyarova & $B \& P$ & Benthic & $\mathrm{i}$ & $\mathrm{p}$ & 7.51 & 16.09 & + \\
\hline aina & Amphora inariensis Krammer & $B \& P$ & Benthic & $\mathrm{m}$ & $\mathrm{p}$ & 0.11 & 1.84 & \\
\hline alan & Planothidium lanceolatum (Brebisson ex Kütz.) Lange-Bertalot & $\mathrm{P}$ & Benthic & i & $\mathrm{p}$ & & 0.01 & \\
\hline amin & Achnanthidium minutissimum (Kütz.) Czarnecki & $B \& P$ & Benthic & $\mathrm{i}$ & $\mathrm{p}$ & 13.20 & 16.71 & - \\
\hline amma & Achnanthidium macrocephalum (Hust.) Round \& Bukhtiyarova & $\mathrm{B}$ & Benthic & $\mathrm{i}$ & $\mathrm{p}$ & 1.93 & & - \\
\hline aped & Amphora pediculus (Kütz.) Grun. & $B \& P$ & Benthic & $\mathrm{m}$ & $\mathrm{p}$ & 0.67 & 2.02 & - \\
\hline caff & Cymbella affinis Kütz. & $B \& P$ & Benthic & $\mathrm{i}$ & $\mathrm{e}$ & 0.44 & 2.04 & - \\
\hline cato & Cyclotella atomus Hust. & B & Planktonic & $\mathrm{i}$ & $\mathrm{s}$ & 5.48 & & - \\
\hline ccae & Encyonema caespitosum Kütz. & $\mathrm{B}$ & Benthic & $\mathrm{i}$ & e & 0.47 & & \\
\hline сcсp & Cyclotella cyclopuncta Hakansson \& Carter & $B \& P$ & Planktonic & $\mathrm{i}$ & $\mathrm{s}$ & 0.02 & 0.21 & \\
\hline ccis & Cymbella cistula (Ehr.) Kirchner & $\mathrm{B}$ & Benthic & $\mathrm{i}$ & e & 1.31 & & \\
\hline chel & Cymbella helvetica Kütz. & $B \& P$ & Benthic & $\mathrm{i}$ & e & 0.69 & 0.81 & + \\
\hline clep & Cymbella leptoceros (Ehr.) Kütz. & B & Benthic & $\mathrm{i}$ & e & 0.12 & & \\
\hline cmen & Cyclotella meneghiniana Kütz. & $B \& P$ & Planktonic & $\mathrm{i}$ & $\mathrm{s}$ & 0.26 & 0.05 & - \\
\hline cmin & Encyonema minutum (Hilse) Mann & $B \& P$ & Benthic & $\mathrm{i}$ & $\mathrm{e}$ & 4.25 & 1.55 & \\
\hline cped & Cocconeis pediculus Ehr. & $B \& P$ & Benthic & $\mathrm{i}$ & $\mathrm{p}$ & 1.61 & 1.87 & - \\
\hline cpla & Cocconeis placentula Ehr. & $B \& P$ & Benthic & $\mathrm{i}$ & $\mathrm{p}$ & 2.11 & 4.11 & - \\
\hline cple & Cocconeis placentula var. euglypta (Ehr.) Grun. & $B \& P$ & Benthic & $\mathrm{i}$ & $\mathrm{p}$ & 1.80 & 0.42 & - \\
\hline cpli & Cocconeis placentula var. lineata (Ehr.) Van Heurck & $B \& P$ & Benthic & $\mathrm{i}$ & $\mathrm{p}$ & 1.64 & 8.52 & - \\
\hline cppl & Cocconeis placentula var. pseudolineata Geitler & $B \& P$ & Benthic & $\mathrm{i}$ & $\mathrm{p}$ & 0.35 & 0.17 & \\
\hline csle & Encyonema silesiacum (Bleisch) Mann & $B \& P$ & Benthic & $\mathrm{i}$ & e & 2.36 & 8.89 & + \\
\hline ctum & Cymbella tumida (Brebisson) Van Heurck & $B \& P$ & Benthic & $\mathrm{i}$ & $\mathrm{e}$ & 0.29 & 1.98 & - \\
\hline dehr & Diatoma Ehrenbergii Kütz. & $B \& P$ & Benthic & $\mathrm{i}$ & c & 2.00 & 0.78 & + \\
\hline dmon & Diatoma moniliformis Kütz. & $B \& P$ & Benthic & $\mathrm{i}$ & $\mathrm{C}$ & 1.34 & 1.09 & + \\
\hline dvul & Diatoma vulgaris Bory & $B \& P$ & Benthic & $\mathrm{i}$ & $\mathrm{C}$ & 4.77 & 1.22 & \\
\hline farc & Fragilaria arcus var. arcus (Ehr.) Cleve & $B \& P$ & Benthic & $\mathrm{i}$ & e & 0.21 & 0.30 & + \\
\hline fcap & Fragilaria capucina var. capucina & $B \& P$ & Benthic & $\mathrm{i}$ & c & 0.15 & 0.03 & \\
\hline fcra & Fragilaria capucina var. vaucheriae (Kütz.) Lange-Bertalot & $B \& P$ & Benthic & $\mathrm{i}$ & $\mathrm{C}$ & 1.01 & 0.51 & \\
\hline glat & Gomphonema lateripunctatum Reichardt \& Lange-Bertalot & $\mathrm{B}$ & Benthic & $\mathrm{i}$ & $\mathrm{e}$ & 0.26 & & \\
\hline gmin & Gomphonema minutum (Ag.) Agardh & $B \& P$ & Benthic & $\mathrm{i}$ & e & 0.53 & 1.83 & \\
\hline gnod & Gyrosigma nodiferum (Grun.) Reimer & $B \& P$ & Benthic & $\mathrm{m}$ & e & 0.08 & 0.19 & \\
\hline goli & Gomphonema olivaceum (Horn.) Brébisson & $B \& P$ & Benthic & $\mathrm{i}$ & e & 3.41 & 2.05 & + \\
\hline gpum & Gomphonema pumilum (Grun.) Reichardt \& Lange-Bertalot & $B \& P$ & Benthic & $\mathrm{i}$ & e & 0.01 & 0.85 & \\
\hline gter & Gomphonema tergestinum Fricke & $\mathrm{P}$ & Benthic & $\mathrm{i}$ & e & & 0.26 & \\
\hline mvar & Melosira varians Agardh & $\mathrm{B} \& \mathrm{P}$ & Benthic & $\mathrm{i}$ & $\mathrm{C}$ & 5.61 & 0.05 & \\
\hline nape & Mayamaea atomus var. permitis (Hust.) Lange-Bertalot & B & Benthic & $\mathrm{m}$ & $\mathrm{p}$ & 0.08 & & \\
\hline nbac & Sellaphora bacillum (Ehr.) Mann & $B \& P$ & Benthic & $\mathrm{m}$ & $\mathrm{p}$ & 0.05 & 0.30 & - \\
\hline ncpl & Nitzschia capitellata Hust. in Schmidt et al. & $B \& P$ & Benthic & $\mathrm{m}$ & e & 0.08 & 0.01 & \\
\hline ncpr & Navicula capitatoradiata Germain & $B \& P$ & Benthic & $\mathrm{m}$ & $\mathrm{p}$ & 1.77 & 0.76 & - \\
\hline ncte & Navicula cryptotenella Lange-Bertalot & $B \& P$ & Benthic & $\mathrm{m}$ & $\mathrm{p}$ & 5.41 & 3.29 & + \\
\hline ndis & Nitzschia dissipata (Kütz.) Grun. & $B \& P$ & Benthic & $\mathrm{m}$ & $\mathrm{e}$ & 8.68 & 0.96 & + \\
\hline nfon & Nitzschia fonticola Grun. in Cleve \& Möller & $B \& P$ & Benthic & $\mathrm{m}$ & e & 5.23 & 0.69 & + \\
\hline nheu & Nitzschia heufleriana Grun. & $B \& P$ & Benthic & $\mathrm{m}$ & e & 0.20 & 0.01 & \\
\hline nlan & Navicula lanceolata (Ag.) Ehr. & $B \& P$ & Benthic & $\mathrm{m}$ & e & 0.33 & 0.18 & \\
\hline nmeg & Navicula antonii Lange-Bertalot & $B \& P$ & Benthic & $\mathrm{m}$ & $\mathrm{p}$ & 0.08 & 0.91 & \\
\hline nmin & Eolimna minima (Grun.) Lange-Bertalot & $B \& P$ & Benthic & $\mathrm{m}$ & $\mathrm{p}$ & 0.01 & 1.20 & \\
\hline npal & Nitzschia palea (Kütz.) Smith & $B \& P$ & Benthic & $\mathrm{m}$ & e & 0.93 & 0.45 & + \\
\hline nphy & Navicula phyllepta Kütz. & $B \& P$ & Benthic & $\mathrm{m}$ & $\mathrm{p}$ & 0.04 & 0.53 & + \\
\hline nrch & Navicula reichardtiana Lange-Bertalot & $B \& P$ & Benthic & $\mathrm{m}$ & $\mathrm{p}$ & 0.94 & 0.35 & + \\
\hline nsem & Sellaphora seminulum (Grun.) Mann & $\mathrm{B}$ & Benthic & $\mathrm{m}$ & $\mathrm{p}$ & 0.33 & & \\
\hline nsit & Nitzschia sinuata var. tabellaria Grun. & $B \& P$ & Benthic & $\mathrm{m}$ & e & 0.24 & 0.20 & \\
\hline ntpt & Navicula tripunctata (Müller) Bory & $B \& P$ & Benthic & $\mathrm{m}$ & $\mathrm{p}$ & 4.43 & 4.13 & + \\
\hline ntrv & Navicula trivalis Lange-Bertalot & $\mathrm{P}$ & Benthic & $\mathrm{m}$ & $\mathrm{p}$ & & 0.22 & \\
\hline nzsu & Nitzschia supralitorea Lange-Bertalot & $\mathrm{P}$ & Benthic & $\mathrm{m}$ & $\mathrm{e}$ & & 0.22 & \\
\hline rabb & Rhoicosphenia abbreviata (Ag.) Lange-Bertalot & $\mathrm{B} \& \mathrm{P}$ & Benthic & $\mathrm{i}$ & e & 0.47 & 0.67 & - \\
\hline rsin & Reimeria sinuata (Gregory) Kociolek \& Stoermer & $B \& P$ & Benthic & $\mathrm{m}$ & e & 0.40 & 2.96 & - \\
\hline sbku & Surirella brebissonii var. kuetzingii Krammer et Lange-Bertalot & B & Benthic & $\mathrm{m}$ & e & 0.64 & & \\
\hline sbre & Surirella brebissonii Krammer \& Lange-Bertalot & $B \& P$ & Benthic & $\mathrm{m}$ & e & 0.16 & 0.11 & \\
\hline
\end{tabular}


phytoplankton throughout the study period. Their contribution to biofilm microphytobenthos was less important, especially during winter. However, biofilm and pelagic zeaxanthin (i.e. cyanobacterial biomarker pigment) were correlated (Spearman, $\mathrm{n}=$ $38, \mathrm{r}=0.41, \mathrm{p}<0.01$ ), whereas biofilm and pelagic chl $b$ (i.e. green algal biomarker pigment) were not (Spearman, $\mathrm{n}=38, \mathrm{r}=0.07, \mathrm{p}=0.7$ ).

A total of 190 diatom species were identified during the study period (Table 1 and Table S1 in the supplement at www.int-res.com/articles/suppl/ a069p047_supp.pdf). Typically benthic species (e.g. Achnantidium spp., Nitzschia spp., Navicula spp.) dominated both in the biofilm and in the water column (Fig. 4). Benthic diatoms were overwhelmingly dominant in the water column, accounting for $99 \%$ of the community throughout the study period. The proportion of typically planktonic species in the biofilm increased up to $34 \%$ during the late summer low water period. This was especially due to the occurrence of Cyclotella atomus, which represented up to $32 \%$ of biofilm diatoms during this period.

\section{Factors influencing diatom species distribution}

Axes 1 and 2 of the RDA performed with the biofilm variables explained 31.5 and $13.8 \%$ of diatom species distribution variance, respectively (Fig. 5a). Biofilm diatom distribution was significantly influenced by temperature, discharge and $\mathrm{pH}$ (Table 2). Axis 1 summarized the opposite patterns of discharge and temperature that were characteristic of the hydrological periods. Diatom taxa associated with low discharge values and high temperatures (mainly Amphora spp., Cocconeis spp., Cyclotella spp., Melosira spp.) scored towards the right side of the biplot, whereas diatom species associated with high discharge values and low temperatures (mainly Achnantes spp., Cymbella spp., Fragilaria spp., Gomphonema spp., Navicula spp., Nitzschia spp.) scored towards the left side of the biplot. A clear trend was also observed when considering diatom structural and mobility properties. Immobile, prostrated and/or solitary forms were associated with higher temperatures, whereas mobile and erected forms were associated with lower temperatures.
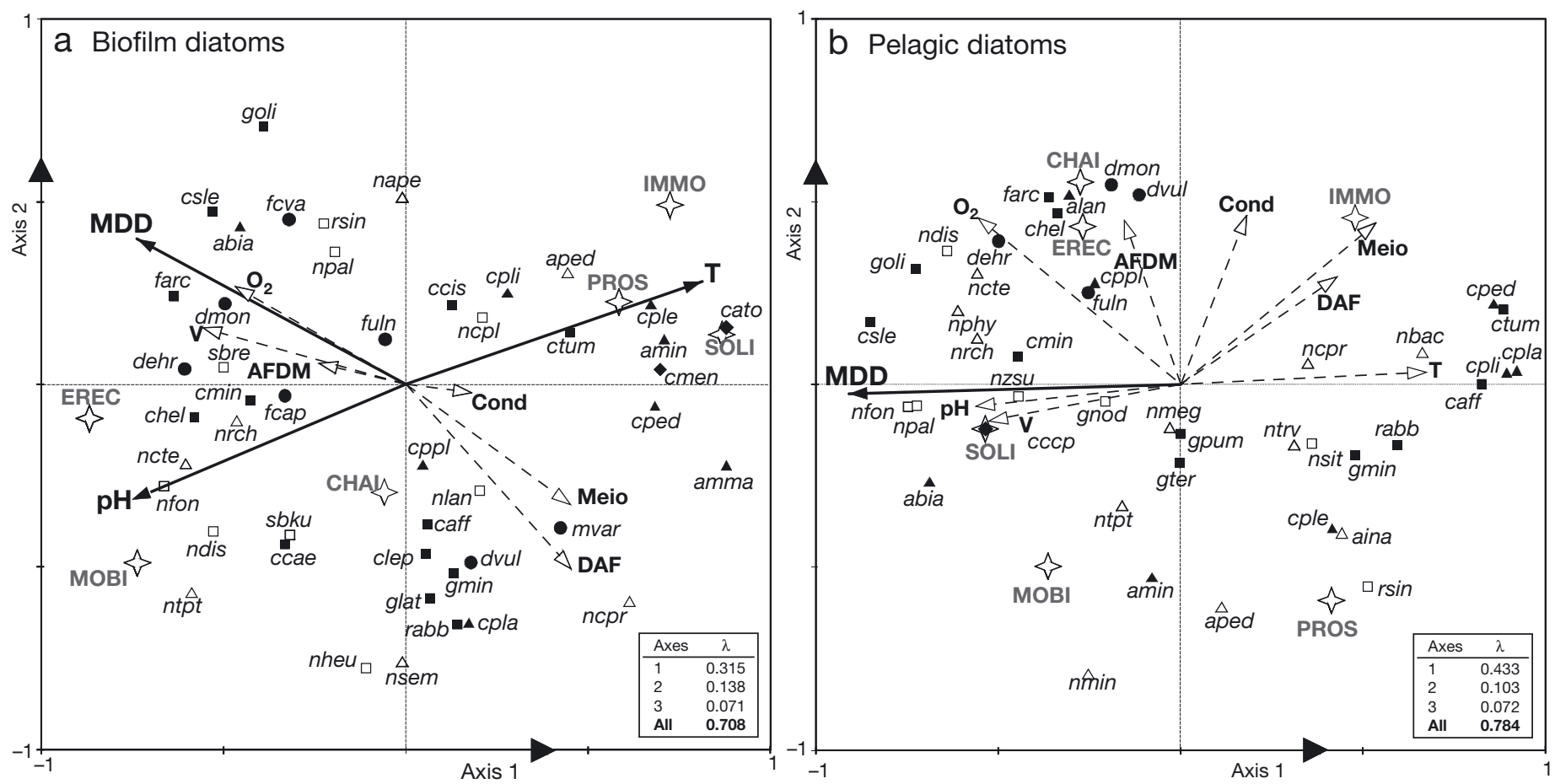

Fig. 5. Redundancy analysis showing the distribution of (a) biofilm and (b) pelagic diatom species' (see Table 1 for abbreviations of species names) relative abundances according to environmental factors. Ordination axes were rescaled from -1 to 1 . Eigenvalues $(\lambda)$ are indicated for main ordination axes. Dashed arrows represent non-significant factors. Bold arrows represent significant factors (Monte Carlo permutation test, $\mathrm{p}<0.05)$. Solid symbols: immobile species; open symbols: mobile species; growth forms - triangles: prostrated; squares: erected; circles: chained; diamonds: solitary centrics. Star symbols represent the summed abundance of species according to their mobility and posture, represented by the groups (IMMO: immobile; MOBI: mobile) and growth forms (PROS: prostrated; EREC: erected; CHAI: chained; SOLI: solitary centrics) (see Table 1). Environmental factor abbreviations - MDD: mean daily discharge; DAF: days after flood; T: temperature; $\mathrm{O}_{2}$ : dissolved oxygen; V: flow velocity; Cond: conductivity; AFDM: biofilm ash-free dry mass; Meio: biofilm-dwelling meiofauna density 
Table 2. Conditional effects from the redundancy analysis (RDA). Each environmental factor is ordered according to its eigenvalue $(\lambda)$, indicating the importance of its own contribution to explain the distribution variance of pelagic and biofilm diatom species. Significant factors at $p<0.05$ are highlighted in bold. MDD: mean daily discharge; DAF: days after flood; $\mathrm{T}$ : water temperature; $\mathrm{O}_{2}$ : dissolved oxygen; $\mathrm{V}$ : flow velocity; Cond: water conductivity; AFDM: biofilm ashfree dry mass; Meio: biofilm-dwelling meiofauna density

\begin{tabular}{|lcc|}
\hline Factor & $\lambda$ & $\mathrm{p}$ \\
\hline RDA pelagic & & \\
MDD & $\mathbf{0 . 3 6}$ & $\mathbf{0 . 0 0 2}$ \\
$\mathrm{O}_{2}$ & 0.08 & 0.068 \\
$\mathrm{~T}$ & 0.06 & 0.100 \\
Cond & 0.06 & 0.158 \\
pH & 0.05 & 0.218 \\
Meio & 0.05 & 0.248 \\
DAF & 0.04 & 0.278 \\
AFDM & 0.04 & 0.352 \\
V & 0.04 & 0.390 \\
RDA biofilm & & \\
T & $\mathbf{0 . 2 4}$ & $\mathbf{0 . 0 0 4}$ \\
MDD & $\mathbf{0 . 1 1}$ & $\mathbf{0 . 0 0 4}$ \\
pH & $\mathbf{0 . 0 9}$ & $\mathbf{0 . 0 0 4}$ \\
DAF & 0.05 & 0.242 \\
Cond & 0.05 & 0.192 \\
AFDM & 0.05 & 0.070 \\
Meio & 0.05 & 0.210 \\
O $_{2}$ & 0.04 & 0.362 \\
V & 0.03 & 0.508 \\
\hline
\end{tabular}

Axes 1 and 2 of the RDA performed with the water column variables explained 43.3 and $10.3 \%$ of the distribution variance of diatom species, respectively (Fig. 5b). Pelagic diatom distribution was largely and significantly influenced by discharge (Table 2). The diatom species' affinities with discharge (seasonality) clearly matched with the distribution patterns observed in the biofilm.

\section{Comparison of biofilm and pelagic diatom communities}

The results of the ANOSIM showed that biofilm and pelagic diatom communities differed most during periods of low flow and high temperatures (Table 3, Fig. 6). Biofilm and pelagic communities became more similar under increasing discharge and decreasing temperatures (i.e. winter conditions). Intra-habitat comparisons showed maximum community differences between low and high discharges (ANOSIM: pelagic, $\mathrm{R}=0.905$; biofilm, $\mathrm{R}=0.656$ ) and between low and high temperatures (ANOSIM: pelagic, $R=0.676$; biofilm, $R=0.899$ ). The $R$-values
Table 3. Test for diatom species composition similarities (ANOSIM) between the water column and the epilithic biofilm, according to discharge and temperature constraints. The R-value and the significance level $\left({ }^{*},{ }^{* *}\right.$ and ${ }^{* * *}$ for $\mathrm{p}<$ $0.05,0.01$ and 0.001 , respectively) are provided. Mean daily discharge (MDD) constraints (in $\mathrm{m}^{3} \mathrm{~s}^{-1}$ ): Low, 0 to 50; Med, 51 to 100 ; High, $>100$. Temperature constraints (in ${ }^{\circ} \mathrm{C}$ ): Low, 0 to 9 ; Med, 9 to 17 ; High, $>17$

\begin{tabular}{|c|c|c|c|}
\hline \multirow{2}{*}{ Biofilm } & \multicolumn{3}{|c|}{ Water column } \\
\hline & Low & Med & High \\
\hline \multicolumn{4}{|l|}{ MDD } \\
\hline Low & $1^{* *}$ & & \\
\hline Med & & $0.66^{* *}$ & \\
\hline High & & & $0.832^{* * *}$ \\
\hline \multicolumn{4}{|c|}{ Temperature } \\
\hline Low & $0.872^{* *}$ & & \\
\hline Med & & $0.865^{* *}$ & \\
\hline High & & & $0.931^{* *}$ \\
\hline
\end{tabular}

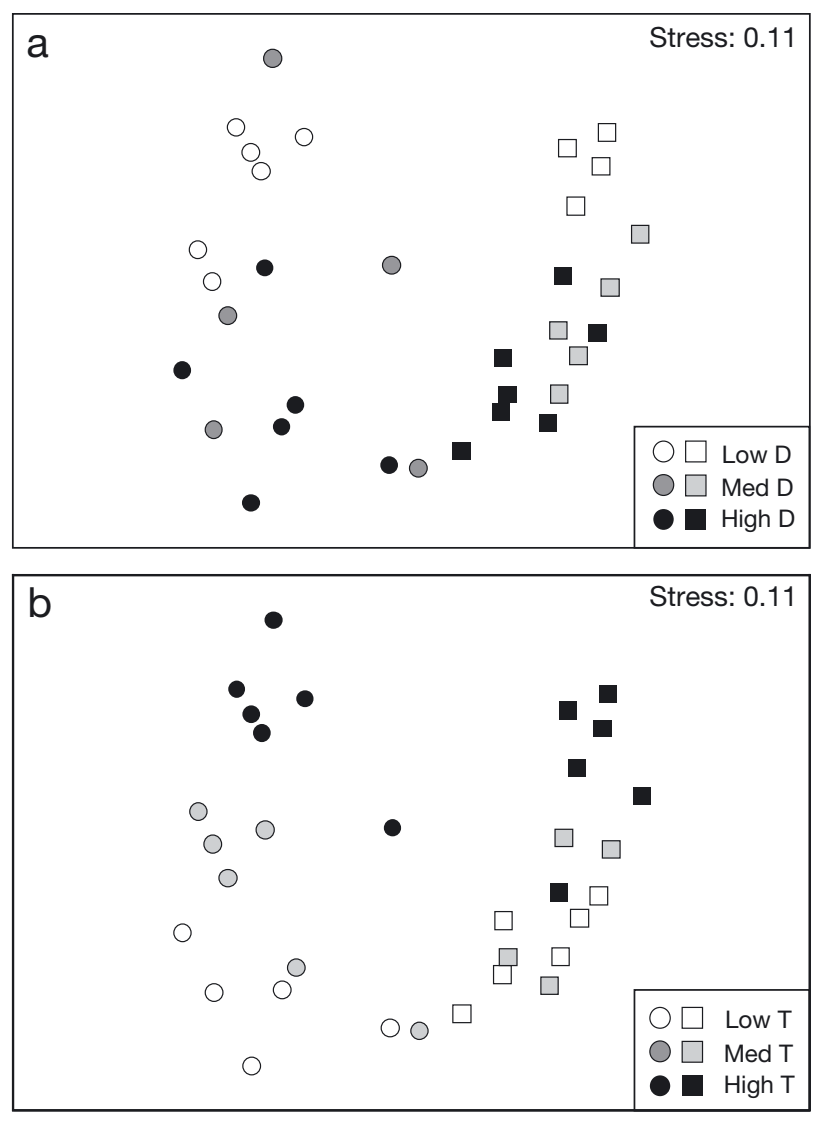

Fig. 6. Non-metric multidimensional scaling plots showing diatom assemblage similarities according to (a) discharge (D) and (b) temperature (T) constraints. Circles: biofilm assemblages; squares: pelagic assemblages. Mean daily discharge constraints (in $\mathrm{m}^{3} \mathrm{~s}^{-1}$ ): Low D, 0 to 50; Med D, 51 to 100; High $\mathrm{D}_{1}>100$. Temperature constraints (in ${ }^{\circ} \mathrm{C}$ ): Low $\mathrm{T}, 0$ to 9 ; Med T, 9 to 17 ; High $\mathrm{T},>17$ 
showed that pelagic communities were more influenced by discharge, while biofilm communities were more influenced by temperature.

\section{DISCUSSION}

The present study showed that phytoplanktonic and phytobenthic communities were generally closely coupled in the middle course of the Garonne River, and decoupling only occurred occasionally. Biofilm and pelagic chl a maxima showed lags that accounted for biofilm self-detachment events which occurred independently of high flow conditions. Furthermore, biofilm chl a was also reduced by flood events, but massive drift of microphytic cells was not detected. Diatoms strongly dominated both phytoplanktonic and phytobenthic communities, as reported by Eulin \& Le Cohu (1998) and Leflaive et al. (2008). Throughout the year, almost all diatom species (99\%) found in the water column were benthic species, sensu Krammer \& Lange-Bertalot (1991). This finding confirms the benthic (biofilm) origin of the diatom cells occurring in the water column. However, planktonic diatom species (mostly Cyclotella atomus) contributed up to $34 \%$ of diatom assemblages in the biofilm during the summer to autumn low water flow period. These planktonic forms were probably derived from upstream lentic areas, including an incipient oxbow lake located $1.3 \mathrm{~km}$ upstream and the Mancies dam located $20 \mathrm{~km}$ upstream of the study site. These reservoirs supply the Garonne with a large number of phytoplankton cells (Ameziane et al. 2003). Planktonic (centric) diatoms are less mobile than those with a raphe (pennate diatoms), and this low mobility could favour their entrapment within the biofilm matrix during low flow conditions in rivers (Roeder 1977).

The pelagic and biofilm diatom communities differed most under periods of low water flow and were more alike under high flow conditions. In our study, the distribution of the diatom species in the 2 compartments and, hence, their benthic-pelagic exchanges were primarily shaped by discharge. This has also been observed by Biggs \& Close (1989) and Uehlinger et al. (1996), who showed that $>60 \%$ of the periphyton biomass variance in streams could be explained by discharge variations. Hudon \& Legendre (1987) determined that the epilithic biofilm architecture was due to a combination of morphology, growth-form and mobility of diatom species, and that the mobile taxa were the most prone to become dislodged by flow velocity. This phenomenon appar- ently occurred in the Garonne, since the presence of mobile taxa in the water column increased with greater discharge (Fig. 5b). However, also within the biofilm, mobile diatoms were more abundant under high flow conditions (Fig. 5a), and therefore the observation could result from the close correspondence between the high occurrence of mobile diatoms in the biofilm matrix and in the water column. The observed species distribution patterns in our study may also be partially explained by the fact that mobile diatoms can display migration behaviour within biofilms (Consalvey et al. 2004) and, thus, can reduce their exposition to flow erosion. Our results also showed that temperature was a significant predictor for diatom distribution in the biofilm. We especially found that erected growth forms occurred during cold months, corroborating the findings of Eulin \& Le Cohu (1998). Solitary centric diatoms and prostrated growth forms, however, mostly occurred in summer, as was observed by Tornés \& Sabater (2010). In the Garonne River, temperature and discharge showed opposite seasonal patterns, and their combination defines a characteristic seasonal gradient which accounts for most of our observed diatom distribution.

During September 2009, the water flow in the Garonne was low and constant, and pelagic chl a increased, whereas biofilm chl a decreased. This unusual uncoupling suggests that factors other than flow or temperature could be involved in benthicpelagic exchanges. Self-detachment of the biofilm is known to occur during low flow periods, which, in the Garonne River, commonly coincide with periods of high temperatures. During these periods, the maturing biofilm shifts towards more heterotrophic assemblages (Peterson et al. 1990, Boulêtreau et al. 2006) and is able to host relevant consumer densities. During September 2009, 90 to 140 meioinvertebrates (mostly nematodes, rotifers and chironomids) dwelled in each square centimetre of biofilm (Majdi et al. 2012a). Although we did not detect meiofaunal density as a significant factor shaping biofilm diatom composition, it is possible that meiofaunal activity could disrupt mat cohesion and could further favour self-detachment processes (e.g. Pinckney et al. 2003, Sabater et al. 2003). Macro-invertebrate grazers can strongly influence biofilm biomass and architecture (Lawrence et al. 2002, Hillebrand 2009). In particular, selective grazing on certain species and avoidance of others can shape microphytic assemblages (e.g. Steinman et al. 1987). In the Garonne biofilms, meiofauna grazes on epilithic diatoms, but the grazing pres- 
sure remains relatively low (Majdi et al. 2012b,c). Moreover, macro-invertebrate grazers (mostly Trichoptera and Ephemeroptera larvae) were abundant on cobbles in early summer and could be responsible for the dramatic reduction in biofilm chl a (Majdi et al. 2012a). Eulin \& Le Cohu (1998) also showed that prostrated diatoms were less often consumed by macro-invertebrates than erected and chained growth forms. Hence, the macro-invertebrate summer grazing pressure could partly explain why erected (Gomphonema spp., Cymbella spp., Nitzschia spp., Surirella spp.) and chained (Fragilaria spp., Diatoma spp., Melosira varians) diatoms dominated during winter, while prostrated diatoms (Cocconeis spp., Amphora spp., Navicula spp.) dominated during summer. However, this suggestion must be considered with caution, since the ecological preferences of diatoms might also influence their distribution. For example, Cocconeis spp. are epiphytes and their summer abundance could also be explained by the increasing availability of macrophytes in Garonne pools and/or of filamentous green algae in the biofilm during summer (Eulin \& Le Cohu 1998).

Our results showed that the epilithic biofilm was an essential and constant provider of diatoms for the water column in the Garonne River, thus corroborating the pioneering work of Roeder (1977). However, during the summer low flow period, susbstantial numbers of planktonic diatoms can settle on the biofilm. While hydrodynamics and temperature (seasonality) primarily shaped these exchanges, biotic processes such as biofilm self-detachment and grazing are suspected to play a role, especially during the summer low flow period. The observed habitat exchanges of both 'benthic' and 'planktonic' diatoms raise the question of the adequacy of the 'benthic' versus 'planktonic' type categorisation. Out of 190 taxa observed in our study, 78 were observed both in the biofilm and in the water column. So apparently, several diatom taxa were not restricted to one or the other habitat, but occurred both on benthic substrata and in the water column. The occurrence of typical 'biofilm' diatoms in the water column during high flow periods shows that at least a part of the diatom community lives in the biofilm and finds itself in the water column at a given moment. Our data did not allow us to discern whether benthic diatoms gave rise to the planktonic population or, if instead, they were transiently exported to the water column. More frequent (e.g. daily) observations under controlled conditions would confirm the possible use of the 2 habitats in the dynamics of diatom species.
Acknowledgements. We thank R. Le Cohu and J. HoneyRosés for their generous help. We also thank F. Julien, S. Boyer and R. Fernandez for field assistance, and 3 anonymous reviewers for their positive feedback and constructive suggestions. This study was funded by a national CNRS EC2CO-CYTRIX program.

\section{LITERATURE CITED}

Ameziane T, Garabetian F, Dalger D, Sauvage S, Dauta A, Capblancq J (2002) Epilithic biomass in a large gravel bed river (the Garonne, France): A manifestation of eutrophication? River Res Appl 18:343-354

> Ameziane T, Dauta A, Le Cohu R (2003) Origin and transport of phytoplankton in a large river: the Garonne, France. Arch Hydrobiol 156:385-404

> Barlow RG, Cummings DG, Gibb SW (1997) Improved resolution of mono- and divinyl chlorophylls $a$ and $b$ and zeaxanthin and lutein in phytoplankton extracts using reverse phase c-8 hplc. Mar Ecol Prog Ser 161:303-307

> Basu BK, Pick FR (1996) Factors regulating phytoplankton and zooplankton biomass in temperate rivers. Limnol Oceanogr 41:1572-1577

Battin TJ, Kaplan LA, Newbold JD, Hansen ME (2003) Contributions of microbial biofilms to ecosystem processes in stream mesocosms. Nature 426:439-442

> Biggs BJF, Close ME (1989) Periphyton biomass dynamics in gravel bed rivers: the relative effects of flows and nutrients. Freshw Biol 22:209-231

Biggs BJF, Kilroy C (2000) Stream periphyton monitoring manual. NIWA, Christchurch

> Borcard D, Legendre P, Drapeau P (1992) Partialling out the spatial component of ecological variation. Ecology 73 : 1045-1055

- Boulêtreau S, Garabetian F, Sauvage S, Sánchez-Pérez JM (2006) Assessing the importance of a self-generated detachment process in river biofilm models. Freshw Biol 51:901-912

Clarke KR, Warwick RM (2001) Changes in marine communities: an approach to statistical analysis and interpretation. PRIMER-E, Plymouth

> Consalvey M, Paterson DM, Underwood GJC (2004) The ups and downs of life in a benthic biofilm: migration of benthic diatoms. Diatom Res 19:181-202

> DeNicola DM, de Eyto E, Wemaere A, Irvine K (2006) Periphyton response to nutrient addition in 3 lakes of different benthic productivity. J N Am Benthol Soc 25:616-631

Dodds WK (2006) Eutrophication and trophic state in rivers and streams. Limnol Oceanogr 51:671-680

Eulin A, Le Cohu R (1998) Epilithic diatom communities during the colonization of artificial substrates in the river Garonne (France). Comparison with the natural communities. Arch Hydrobiol 143:79-106

Gaudes A, Sabater S, Vilalta E, Muñoz I (2006) The nematode community in cyanobacterial biofilms in the river Llobregat, Spain. Nematology 8:909-919

Hillebrand H (2002) Top-down versus bottom-up control of autotrophic biomass: a meta-analysis on experiments with periphyton. J N Am Benthol Soc 21:349-369

> Hillebrand H (2009) Meta-analysis of grazer control of periphyton biomass across aquatic ecosystems. J Phycol 45: 798-806

Hudon C, Legendre P (1987) The ecological implications of growth forms in epibenthic diatoms. J Phycol 23:434-441 
Kathol M, Fischer H, Weitere M (2011) Contribution of biofilm-dwelling consumers to pelagic-benthic coupling in a large river. Freshw Biol 56:1160-1172

Korte VL, Blinn DW (1983) Diatom colonization on artificial substrata in pool and riffle zones studied by light and scanning electron microscopy. J Phycol 19:332-341

Krammer K, Lange-Bertalot H (1991) Bacillariophyceae, Vols 1 to 4. Spektrum Akademischer Verlag, Heidelberg

> Lawrence JR, Scharf B, Packroff G, Neu TR (2002) Microscale evaluation of the effects of grazing by invertebrates with contrasting feeding modes on river biofilm architecture and composition. Microb Ecol 44:199-207

> Leflaive J, Ten-Hage L (2007) Algal and cyanobacterial secondary metabolites in freshwaters: a comparison of allelopathic compounds and toxins. Freshw Biol 52: 199-214

> Leflaive J, Boulêtreau S, Buffan-Dubau E, Ten-Hage L (2008) Temporal patterns in epilithic biofilm - relation with a putative allelopathic activity. Fundam Appl Limnol 173:121-134

Liess A, Hillebrand H (2004) Invited review: direct and indirect effects in herbivore-periphyton interactions. Arch Hydrobiol 159:433-453

Lock MA, Wallace RR, Costerton JW, Ventullo RM, Charlton SE (1984) River epilithon: toward a structural-functional model. Oikos 42:10-22

- Lyautey E, Jackson CR, Cayrou J, Rols JL, Garabetian F (2005a) Bacterial community succession in natural river biofilm assemblages. Microb Ecol 50:589-601

Lyautey E, Lacoste B, Ten-Hage L, Rols JL, Garabetian F (2005b) Analysis of bacterial diversity in river biofilms using 16s rDNA PCR-DGGE: methodological settings and fingerprints interpretation. Water Res 39:380-388

Mackey MD, Mackey DJ, Higgins HW, Wright SW (1996) CHEMTAX - a program for estimating class abundances from chemical markers: application to HPLC measurements of phytoplankton. Mar Ecol Prog Ser 144:265-283

Majdi N, Traunspurger W, Boyer S, Mialet B and others (2011) Response of biofilm-dwelling nematodes to habitat changes in the Garonne River, France: influence of hydrodynamics and microalgal availability. Hydrobiologia 673:229-244

Majdi N, Mialet B, Boyer S, Tackx M and others (2012a) The relationship between epilithic biofilm stability and its associated meiofauna under two patterns of flood disturbance. Freshw Sci 31:38-50

> Majdi N, Tackx M, Buffan-Dubau E (2012b) Trophic positioning and microphytobenthic carbon uptake of biofilmdwelling meiofauna in a temperate river. Freshw Biol 57: 1180-1190

> Majdi N, Tackx M, Traunspurger W, Buffan-Dubau E (2012c) Feeding of biofilm-dwelling nematodes examined using HPLC-analysis of gut pigment contents. Hydrobiologia 680:219-232

> Mathieu M, Leflaive J, Ten-Hage L, de Wit R, Buffan-Dubau E (2007) Free-living nematodes affect oxygen turnover of artificial diatom biofilms. Aquat Microb Ecol 49:281-291

Passy SI (2007) Diatom ecological guilds display distinct and predictable behaviour along nutrient and disturbance gradients in running waters. Aquat Bot 86:171-178

Peterson CG, Hoagland KD, Stevenson RJ (1990) Timing of wave disturbance and the resistance and recovery of a freshwater epilithic microalgal community. J N Am Benthol Soc 9:54-67
Phlips EJ, Cichra M, Aldridge FJ, Jembeck J, Hendrickson J, Brody R (2000) Light availability and variations in phytoplankton standing crops in a nutrient-rich blackwater river. Limnol Oceanogr 45:916-929

> Pinckney JL, Carman KR, Lumsden SE, Hymel SN (2003) Microalgal-meiofaunal trophic relationships in muddy intertidal estuarine sediments. Aquat Microb Ecol 31: 99-108

> Pusch M, Fiebig D, Brettar I, Eisenmann H and others (1998) The role of micro-organisms in the ecological connectivity of running waters. Freshw Biol 40:453-495

> Reynolds CS, Descy JP, Padisak J (1994) Are phytoplankton dynamics in rivers so different from those in shallow lakes? Hydrobiologia 289:1-7

> Roeder DR (1977) Relationships between phytoplankton and periphyton communities in a central Iowa stream. Hydrobiologia 56:145-151

Romaní AM, Guasch H, Munoz I, Ruana J and others (2004) Biofilm structure and function and possible implications for riverine DOC dynamics. Microb Ecol 47:316-328

Sabater S, Guasch H, Romaní AM, Muñoz I (2002) The effect of biological factors on the efficiency of river biofilms in improving water quality. Hydrobiologia 469:149-156

Sabater S, Vilalta E, Gaudes A, Guasch H, Munoz I, Romaní AM (2003) Ecological implications of mass growth of benthic cyanobacteria in rivers. Aquat Microb Ecol 32: 175-184

Sabater S, Artigas J, Duran C, Pardos M, Romaní AM, Tornés E, Ylla I (2008) Longitudinal development of chlorophyll and phytoplankton assemblages in a regulated large river (the Ebro River). Sci Total Environ 404: 196-206

> Soetaert K, Herman PMJ (1995) Carbon flows in the Westerschelde estuary (The Netherlands) evaluated by means of an ecosystem model (MOSES). Hydrobiologia 311: $247-266$

> Steinman AD, McIntire CD, Gregory SV, Lamberti GA, Ashkenas LR (1987) Effects of herbivore type and density on taxonomic structure and physiognomy of algal assemblages in laboratory streams. J N Am Benthol Soc 6: 175-188

Teissier S, Torre M, Delmas F, Garabetian F (2007) Detailing biogeochemical $n$ budgets in riverine epilithic biofilms. J N Am Benthol Soc 26:178-190

Ter Braak CJF (1987) Ordination. In: Jongman RHG, Ter Braak C JF, Van Tongeren OFR (eds) Data analysis in community and landscape ecology. Cambridge University Press, Cambridge, p 91-173

Ter Braak CJF (1994) Canonical community ordination, Part I: basic theory and linear methods. Ecoscience 1:127-140

Ter Braak CJF, Smilauer P (2002) CANOCO reference manual and CanoDraw for windows user's guide - software for canonical community ordination (Version 4.5). Microcomputer Power, Ithaca, NY

> Tornés E, Sabater S (2010) Variable discharge alters habitat suitability for benthic algae and cyanobacteria in a forested Mediterranean stream. Mar Freshw Res 61: 441-450

Uehlinger U, Bührer H, Reichert P (1996) Periphyton dynamics in a floodprone prealpine river: evaluation of significant processes by modelling. Freshw Biol 36: 249-263

> Vannote RL, Minshall GW, Cummins KW, Sedell JR, Cushing CE (1980) The river continuum concept. Can J Fish Aquat Sci 37:130-137 